\title{
GLOBAL PERSPECTIVE FOR PROTECTING INTELLECTUAL PROPERTY - PATENTING IN USA AND POLAND
}

\author{
Michalene Eva GREBSKI \\ Northampton Community College - Monroe Campus \\ Radosław WOLNIAK \\ Silesian University of Technology
}

\begin{abstract}
:
Paper addresses the different methods for protecting intellectual property in modern knowledge-based economies. The focus of the paper is a comparison between the procedures for applying for patents in Poland and the United States. The comparison has been made from the perspective of the cost of obtaining and maintaining a patent in Poland, the United States and some other countries. The comparison has also been made from the perspective of the procedures for applying for a patent in different countries based on the Patent Cooperation Treaty. The paper also includes a comparison of the time needed for processing the patent application. Low cost provisional twelve-month patent pending protection available in the United States is also being discussed. The paper also provides some guidance and recommendations for conducting a patent search in order to validate the originality of the invention.
\end{abstract}

Key words: patents, patent, intellectual property, intellectual property law, innovations, Polish patents, US patents

\section{INTRODUCTION}

The advancements in communication technology (internet as well as inexpensive and rapid methods of transportation) converted the world into a global society. The boundaries between countries are almost invisible and free trade converted regional economies into one global economy. There are still significant differences between the availability and the cost of the workforce in different parts of the world. Manufacturing businesses are gravitating into areas with lower labor costs. There are many areas in the world with lower labor costs and sufficient technology which can produce quality products. The profit margin in manufacturing has decreased and became less attractive to countries with high labor costs [20, 21, 22]. The world center for car manufacturing used to be Detroit, Michigan. Then it became Japan. Presently it is Korea. In the future, it may become India and China. One way to bring manufacturing back to countries with high labor costs is by applying full automation in the manufacturing process. Therefore, countries and regions of the world with high labor costs have become knowledge-based economies [2]. Europe and North America have become knowledge-based economies. An innovative and creative workforce in those countries is a driving force creating economic prosperity. Innovativeness and creativity are highly profitable activities producing intellectual property. Protecting intellectual property is essential in knowledge-based economies in order to generate profit which is needed to fuel the economy $[19,23,24,25$, 26].

\section{METHODS AND FORMS OF INTELLECTUAL PROPRIETY}

\section{Methods for Protecting Intellectual Property}

There are methods for protecting intellectual property. They are as follows [11]:

- To maintain a company's secret.

Every employee who has access to a company secret needs to sign a confidentiality agreement to protect the secret. The employee would be obligated to protect the company's secret even after retirement or termination of employment. Coca-Cola's ingredients have been and are still protected by a company secret for over fifty years. If the company would have chosen patent protection fifty years ago, the patent would have expired after twenty years. Therefore, the ingredients would have been in the public domain for the last thirty years.

- Patent, trademark or copyright protection.

\section{Forms of Intellectual Property}

One of the roles of governments in modern society is "to promote the progress of science and useful arts by securing for limited times to authors and inventors the exclusive right to their respective writings and discoveries". (Article 1, Section 8, United States constitution) [1, 12]. Intellectual property is the legal right to an invention, copyright or trademark. Intellectual property like any other property can be bought, sold or inherited [11].

1. Patent

A patent is a grant of the property right to the inventor which is issued by a patent or trademark office. New 
patent protection is granted for twenty years from the date when the application for the patent was filed. The owner of the patent has the rights to exclude others from making, using, offering for sale, selling or importing the invention. Patent protection is only in the country where the patent has been issued. The three different types of patents are as follows:

- Utility Patent

A utility patent protects the invention of any new or useful process, machine, article to be manufactured or any new useful improvement.

- Design Patent

A design patent protects new, original or ornamental designs to be manufactured.

- Plant Patent

A plant patent protects discoveries of asexually reproduced new variety of plants.

2. Trademark

Trademark is defined as a symbol or device which is being used in the process of trading goods and to indicate the source of goods, for example, the Coca-Cola symbol.

Trademark protection prevents others from using a confusingly similar symbol, but it does not prevent others from selling the same goods using a different trademark [11].

3. Copyright

Copyrights protect original works of authorship. They give the author exclusive rights to reproduce their copyrighted work. Copyrights protect any form of expression. Those form of expression include, but are not limited to music, dramatic work and other intellectual work either published or unpublished $[11,14]$.

This paper focuses on patent protection with an emphasis on utility patents. Utility patents can be technical solutions which satisfy the following criteria:

- new inventions (Not part of a technical solution),

- not obvious (For somebody who is familiar with the current technology),

- suitable for industrial application,

- not published previously in scientific or technical publications,

- not patented previously.

Scientific discoveries are not patentable. Technical solutions based on scientific discoveries are patentable.

Ownership of the Patent 14]:

Ownership of a patent can be granted as follows [11,

- Author of the invention if the invention was not created as a part of the inventor's employment responsibility.

- Companies where the author is employed if the invention came as a part of employment.

Many employers have very specific regulations related to ownership of a patent. Most employees of public and private universities as well as employees of research and development companies are required to sign an agreement relinquishing to the company the ownership of the intellectual property which was developed during the time of employment. In that case, the company as the owner can market the patent, but the inventor as the author is entitled to $50 \%$ of the profit generated by the patent. The company as the owner of the patent is responsible for paying all fees associated with obtaining and maintaining the patent.

\section{PROCEDURE FOR SECURING A PATENT IN USA}

The preparation for a patent application requires the knowledge of patent law as well as scientific and technical matters which are involved in an invention. Inventors may prepare their own application, file it at the patent office and continue the process themselves. However, many inventors chose to employ the services of a licensed patent attorney or patent agent. Both patent attorneys and patent agents are permitted to prepare a patent application and conduct the procedures as a representative of the inventor [8]. When the registered patent attorney has been appointed, the patent office does not communicate with the inventor directly, but conducts the correspondence with the patent attorney or patent agent. The fees charged to the inventor by patent attorneys or patent agents for their professional services are not subject to regulation by the patent office [9]. Officers employed by the patent office are prohibited by law to apply for patents except by inheritance. In the United States, there is a website as a resource for independent inventors.

The application for a patent needs to include the following [11]:

- patent application,

- description of the invention,

- summary of the invention description,

- drawing or sketches, as appropriate,

- filing, application, search and examination fees,

- application submitted to United States Patent Office requires "claim and oath" signed in front of a government official.

Then the patent office is conducting a patent search to check originality of the invention.

Provisional Patent Protection as a Low-cost Valuable Alternative

Since June 8, 1995, the United States Patent Office has offered inventors the option of filing a provisional application for a patent. This was done to provide low-cost patent filing. "Claims and oath" are not required for a provisional application. A provisional application allows the patent office to establish an early effective filing date for a patent application. It also allows the term "patent pending" to be used with the invention. A provisional application can only be filed for a utility patent. The filing date of the provisional application is the date on which the written description of the invention and drawings (if necessary) are received by the United States Patent Office. The provisional application needs to include a \$260 filing fee and a cover sheet indicating that the application is provisional. Then the applicant has twelve months to file a non-provisional application. The filing date of the non-provisional application is retroactive and matches the filing date for the provisional patent. If a non-provisional application is not filed within twelve months, the provisional patent expires. A provisional patent application is not being checked for merit and can be filed in any language. A provisional patent application is a very valuable option for new entrepreneurs and small companies in the incubation stage. A provisional patent provides them with twelve months protection for a $\$ 260$ fee. Companies at the beginning stage of operation can start to market the product based on the invention. They can also check the market value of the patent by being able to disclose the idea to perspective buyers. If the business venture based on the invention is demonstrating sufficient growth, the profit which is generated can be used to apply for a non 
-provisional patent. If the invention does not generate any profit, the inventor can abandon the idea before investing more financial resources to pay for a non-provisional patent [14].

\section{Patent Rules and Regulations in the United States}

Citizens of any country can apply for a patent in the United States. The procedure to apply for a patent in the United States is as follows:

- To submit the application for a provisional patent.

(This step is optional and provides protection for up to 12 months at a very low cost. During the 12-month period, the inventor is under the protection of "patent pending" status.)

- To submit the application for a nonprovisional patent.

United States citizens applying for a foreign patent need one of the following prior to applying for an international patent:

- To apply for a United States patent.

(This application needs to be done up to 12 months prior to applying for the foreign patent.)

- To secure written permission from the United States Patent Office to apply for the foreign patent without applying for the United State patent.

Within 18 months, the patent office publishes a description of the invention. The fees charged by Patent Office in the United States are shown in Table 1 and Table 2. The patent is being issued 2.5 years from the application date $[8,16,17,18]$. After the patent application has been submitted, the author has 12 months to apply for a patent in other countries (Fig. 1).

Table 1 Fees charged by the patent office in the United States

\begin{tabular}{ll}
\hline Filing fee for a patent application & $\$ 280$ \\
Electronic filing of a patent application & $\$ 280$ \\
Filing fee for a provisional application & $\$ 260$ \\
Patent search fee & $\$ 600$ \\
Patent examination fee & $\$ 720$ \\
Patent issuing fee & $\$ 960$ \\
Processing fee (except for a provisional patent) & $\$ 140$ \\
Processing fee for a provisional patent & $\$ 50$ \\
\hline
\end{tabular}

Source: [15]

Table 2

Fees associated with yearly maintenance of patent protection in the United States

\begin{tabular}{ll}
\hline Payable at 3.5 years for patent protection & $\$ 1,600$ \\
Payable at 7.5 years for patent protection & $\$ 3,600$ \\
Payable at 11.5 years for patent protection & $\$ 7,400$ \\
\hline
\end{tabular}

Source: [15]

Fees associated with a patent attorney or patent agent are not being regulated by the United States Patent Office or any other government or state agency. The fees are ne- gotiated between the patent attorney/patent agent and the client (person/company) applying for the patent.

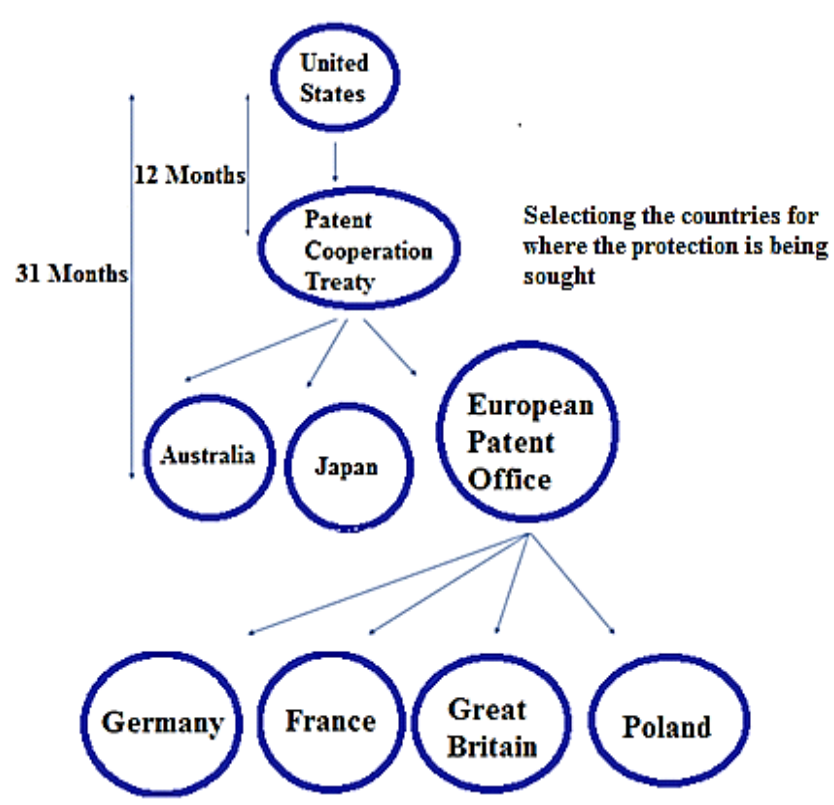

Fig. 1 Applying for a patent in various countries (from the United States)

Source: [14].

When applying for patent protection in other countries from United States (Fig. 1), there are three options. They are as follows [14]:

- To apply for patent protection in the selected country following the rules and procedures of that country.

- To apply for patent protection in the European Patent Office (EPO).

Based on one application, a patent can be granted in most European countries. The location of the European Patent Office is Munich, Germany. The accepted languages are English, German and French. The fees charged by the European Patent Office are shown in Table 3.

- To apply for patent protection under the Patent Cooperation Treaty (PCT).

Based on one application a patent can be granted in most countries which are part of the Patent Cooperation Treaty. The location of the PCT office is Geneva, Switzerland. The fees charged by the International Patent Office in Geneva are shown in Table 4.

Table 3 Patent fees charged by the European Patent Office in Munich, Germany.

\begin{tabular}{ll}
\hline Filing fee & 210 Euro \\
$\begin{array}{l}\text { Patent search to check originality } \\
\text { of the invention }\end{array}$ & 1,635 Euro \\
$\begin{array}{l}\text { Fee for protection in one or more European } \\
\text { countries }\end{array}$ & 585 Euro \\
\hline
\end{tabular}

Source: [4] 


\begin{tabular}{lc}
\hline \multicolumn{1}{c}{ International patent fees $\begin{array}{r}\text { (International Patent Office } \\
\text { in Geneva, Switzerland) }\end{array}$} \\
\hline Transmittal fee & $\$ 240$ \\
Non-electronic filing fee (filed by paper) & $\$ 400$ \\
$\begin{array}{l}\text { Patent search fee (required even if conducted } \\
\text { previously) }\end{array}$ & $\$ 2,080$ \\
$\begin{array}{l}\text { Transmitting application to International Patent } \\
\text { Office }\end{array}$ & $\$ 240$ \\
Examination fee & $\$ 600$ \\
Handling fee & $\$ 206$ \\
\hline
\end{tabular}

Source: [4] www.wipo.int/hague/en/fees/sched.htm. [DOA: $11 / 30 / 2017]$.

Seven Steps in a Preliminary Search of United States Patents and a Published Patent Application

When the applicant is writing a description of the invention, there is always a need to conduct a patent search to identify if any similar solution already exists. If similar solutions already exist, the inventor can either abandon the idea or explain how the invention is different. The procedure for a patent search is as follows $[16,17]$ :

1. Brainstorm terms.

2. Find relevant "Cooperative Patent Classification" (CPC). (www.uspto.gov)

3. Review the CPC definition.

4. Retrieve U.S. patent documents with the CPC that you selected. (Patents Full-Text and Image) database (http://patft.uspto.gov)

5. Review relevant patent publications for similarity to your own invention.

6. Retrieve U.S. published patent applications with the CPC selected in Step 3 in the "Applications Full-Text and Image" (AppFT). (http://appft.uspto.gov)

7. Find additional U.S. patent publications by searching PatFT or AppFT databases, European Patent Office's espacenet patent database (http:// worldwide.espacenet.com) and the nearest Patent and Trademark Resource Center (http://www.uspto.gov/ ptrc).

Patent searches conducted by the inventor lead to a significant saving in patent attorney or patent agent fees.

\section{APPLYING FOR A PATENT IN POLAND}

Polish citizens living in Poland must apply for a patent in Poland before applying for a patent in any other countries. The cost of patent procedures in Poland is shown in Table 1 $[9,10]$.

The patent procedure in Poland is as follows [3].

- submit a patent application,

- within 12-18 months, patent office publishes the description of the invention (for 8 months from the time that the description was published, anyone may submit objections),

- from the day the description is published, the patented invention is legally protected,

- patent is being issued 4-5 years from the application date,
- after the patent application has been submitted, the author has 12 months to apply for a patent in other countries (12-month priority period).

The cost associated with applying and maintaining a patent in Poland is shown in Table 5 and Table 6 [6].

Table 5

Fees charged by the patent office in Poland

\begin{tabular}{lc}
\hline Filing of the patent application & 140 Euro \\
$\begin{array}{l}\text { Electronic filing of a patent application } \\
\text { Sending the application to the European Patent }\end{array}$ & 125 Euro \\
$\begin{array}{l}\text { Office } \\
\text { Sending the application to the International Patent } \\
\text { Office } \\
\text { Fees for challenging a patent }\end{array}$ & 140 Euro \\
\hline
\end{tabular}

Source: [11].

Table 6

Fees associated with the yearly maintenance of patent protection (in Poland)

\begin{tabular}{lc}
\hline First 3 years of protection & 120 Euro \\
$5^{\text {th }}$ year of protection & 75 Euro \\
$10^{\text {th }}$ year of protection & 165 Euro \\
$15^{\text {th }}$ year of protection & 265 Euro \\
$20^{\text {th }}$ year of protection & 390 Euro \\
\hline
\end{tabular}

Source: [11].

Fees associated with a patent attorney or patent agent are not regulated by the Polish patent office and the fees can be negotiated between the patent attorney and the client.

\section{APPLYING FOR A PATENT IN OTHER COUNTRIES (FROM POLAND)}

Very often patent protection in your own country is not sufficient. Often there is a need to seek patent protection in other countries as well. The procedure (Fig. 2) for that would be as follows $[2,5,7,10,11,13]$.

1. Within 12 months from the day of applying for a patent in Poland, the patent owner can apply for a patent in other counties following that country's procedures.

2. If the patent owner wants patent protection in a number of other countries, it is advisable to apply for a patent through the following agencies.

- European Patent Office (EPO) in Munich, Germany One patent application to the EPO can lead to obtaining a patent in all European counties. Fig 3. (The countries for patent protection need to be selected).

- International Patent Office in Geneva, Switzerland which is operating under Patent Cooperation Treaty (PCT).

The country where protection is being sought needs to be mentioned in the application for the patents (including the United States).

3. Some countries require a product protected by a patent to be manufactured in that country for a specified time (for example, 3 years). 


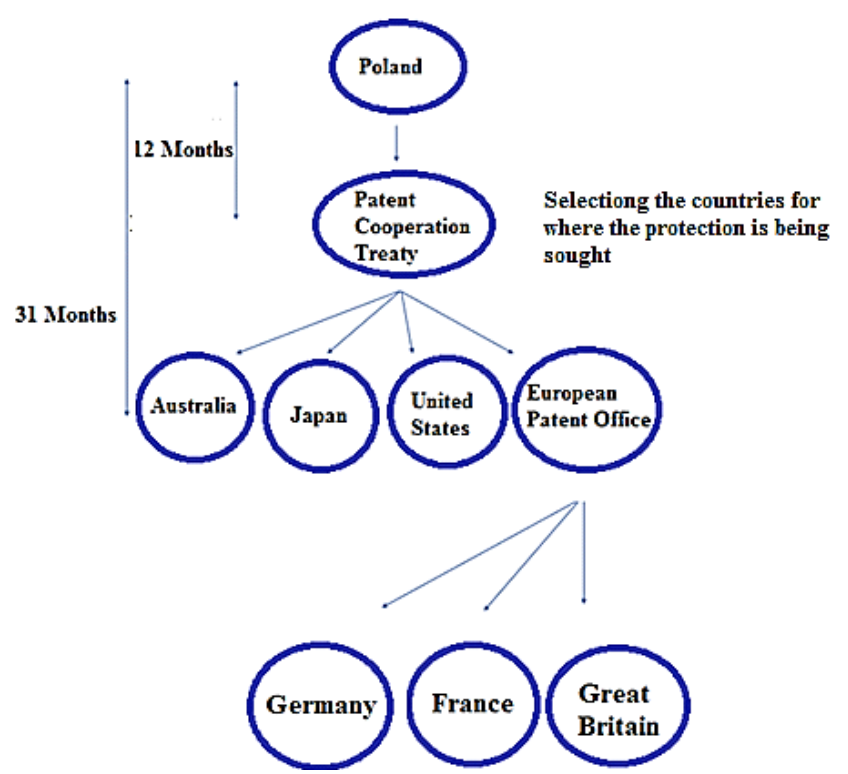

Fig. 2 Applying for a patent in various countries around the world (from Poland)

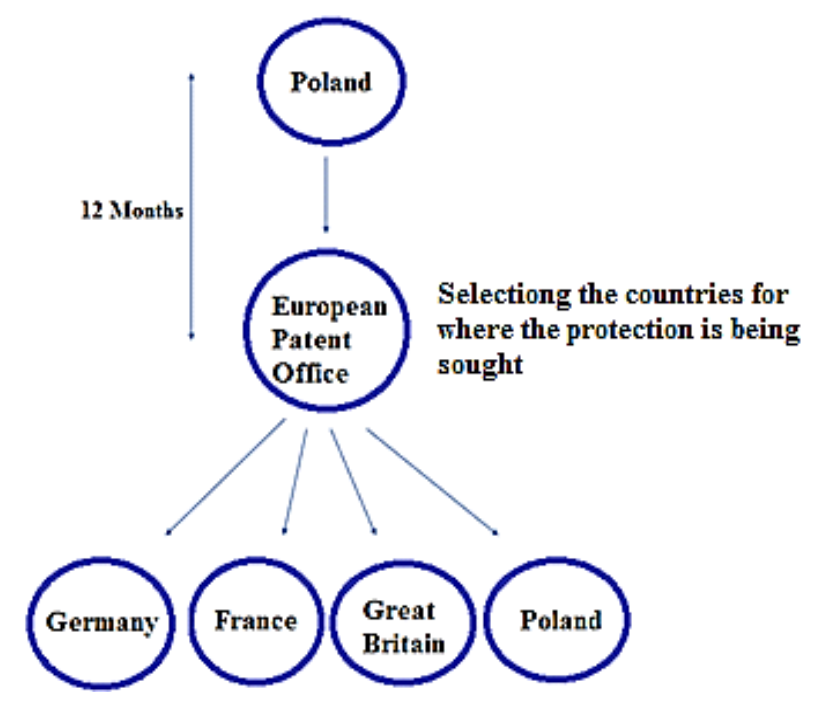

Fig. 3 Applying for patent in Europe (from Poland)

\section{CONCLUSIONS}

Table 7 includes a summary of the costs and timeframe when applying for patent protection in selected European and non-European countries.

Preparing and submitting a patent application can be done by the inventor. The guidelines related to the format of the patent application as well as the required documentation and procedure are available online. If the inventor is associated with a business incubator center, the assistance in completing the patent application may be available free of charge. Often there are grants available to offset the cost of the procedure. If the inventor choses to hire a patent attorney or patent agent, the cost of the procedure can either double or triple. Patent protection is only valid in the country issuing the patent. The laws of that country prevent the manufacturing, marketing and selling of a product affected by the invention. Therefore, the inventors in larger countries have an advantage over the inventors from smaller countries. For inventors living in smaller countries, there is a need to apply for patent protection in some of the larger countries as well. Provisional patent protection which is available in the United States is a very valuable alternative for new inventors. The inventor can get patent protection for twelve months in the form of "patent pending" status. During that time, they can disclose and market the inven-

Table 7

Cost and timeframe of applying for patent protection

\begin{tabular}{|c|c|c|}
\hline Country & Cost & $\begin{array}{l}\text { Time (before pa- } \\
\text { tent is granted) }\end{array}$ \\
\hline $\begin{array}{l}\text { United States (Patent } \\
\text { pending "Provisional") }\end{array}$ & $\$ 260$ & $\begin{array}{l}\text { Immediately (Up } \\
\text { to } 12 \text { months) }\end{array}$ \\
\hline $\begin{array}{l}\text { United States (Non- } \\
\text { provisional) }\end{array}$ & $\begin{array}{l}\$ 5,000- \\
\$ 10,000\end{array}$ & 2.5 years \\
\hline Poland & $\begin{array}{l}\$ 1,250- \\
\$ 3,600\end{array}$ & $4-5$ years \\
\hline United Kingdom & $\begin{array}{l}\$ 8,000- \\
\$ 9,400\end{array}$ & 2.5 years \\
\hline $\begin{array}{l}\text { Patent Protection in Eu- } \\
\text { rope ( } 7 \text { countries) }\end{array}$ & $\$ 16,000$ & 2.5 years \\
\hline $\begin{array}{l}\text { Additional Non-European } \\
\text { Countries }\end{array}$ & $\begin{array}{l}\$ 4,000- \\
\$ 13,500\end{array}$ & 2.5 years \\
\hline
\end{tabular}

tion. "Patent pending" status allows the inventor to test the market or generate a profit to apply for a nonprovisional patent within twelve months. This concept would be a very valuable alternative in Poland as well.

\section{REFERENCES}

[1] Amendment to the United States Constitution. Internet: https://www.archives.gov/founding-docs/ amendments-11-27 [Jan. 19, 2017].

[2] G. Bush. Poland Business and Economic Relations Treaty: Poland Concerning Business and Economic Relations. Message From the President of the United States. Signed 03/21/1990. Amended 05/01/2004. Washington, D.C.: United States Government Printing Office, 1990, pp. 1-22.

[3] Dziennik Ustaw: Rzeczypospolitej Polskiej. Prawo własności przemysłowej z 2003, nr 119, poz 1117, ze zmianami z dnia. pp. 1-49, https://www.google.pl/ url?

$\mathrm{sa}=\mathrm{t} \& \mathrm{rct}=\mathrm{j} \& \mathrm{q}=\& \mathrm{esrc}=\mathrm{s} \&$ source $=$ web $\& \mathrm{~cd}=4 \&$ ved $=0 \mathrm{ah}$ UKEwjSOLq6quPYAhXBalAKHT6iDtMQFgg6MAM\&url= http\%3A\%2F\%2Fpatenty.bg.agh.edu.pl\%2Fgraf\% 2Fprawo2003 119 1117.pdf\&usg=AOvVaw1bdKN4JK _0QRKRzKp2g0Hn [Jan. 19. 2018].

[4] European Patent Office. Forms and fees for patent application. Internet: www.epo.org/applying/formsfees/fees.html [Nov. 30, 2017].

[5] A. Pawłowski. Zgłoszenia patentowe PCT. Internet: www.eupatent.pl/blog/2013/06/05/zgloszeniapatentowe-pct, Jun. 5, 2013, [Nov. 30, 2017].

[6] Polish Patent Office and World Intellectual Property Organization. "Czerpiąc z przeszłości, kreuj przyszłość. Wynalazki i patenty". Internet: www.uprp.pl/ _gAllery/58/36/58360/ czerpiac_z_przeszlosci_2012.pdf [Dec. 24, 2017].

[7] Polish Patent Office. National procedure is initiated the application (administration) of the applicant addressed the Patent Office for protection reported to he solution (eg. An invention or a utility model). Internet: www.uprp.pl/procedura-krajowa/ Lead05,24,1708,4,index,pl,text/ [Dec. 24, 2017]. 
[8] R.A. Posner. "Why There are Too Many Patents in America". Internet: www.theatlantic.com/business/ archive/2012/07/why-there-are-too-many-patents-inamerica/259725/, Jul. 12, 2012 [Dec. 24, 2017].

[9] Procedury patentowe. Internetowe centrum przedsiębiorczości akademickiej, Wrocław 2010. https:// www.google.pl/url?

$\mathrm{sa}=\mathrm{t} \& \mathrm{rct}=\mathrm{j} \& \mathrm{q}=\& \mathrm{esrc}=\mathrm{s} \&$ source $=$ web $\& \mathrm{~cd}=1 \& \mathrm{cad}=\mathrm{rja} \&$ uact $=8 \&$ ved=0ahUKEwjr3NHBqePYAhVRKVAKHR6tDq 8QFggrMAA\&url=http\%3A\%2F\%2Ficpa.pl\%2Fsites\% 2Ficpa.pl\%2Ffiles\%2Fprocedurypatentowe.pdf\&usg=AOvVaw3RIsZpxIkz8AXIPZmTgZ18, [Jan. 19. 2018].

[10] Raport o stanie patentowania w Polsce - patenty szansą na wzrost innowacyjności polskich przedsiębiorców. Cirdo Taxend, Warszawa, 2015.

[11] A. Śnieżko. Jak chronić wynalazki w Polsce, w Europie i na świecie: Podstawowe pojęcia i procedury. Internet: wtspatent.pl/wp-content/uploads/2014/05/pl.1.pdf [Nov. 30, 2017].

[12] The Constitutio of The United States: A Transcription. Internet: https://www.archives.gov/founding-docs/ constitution-transcript [Jan. 19, 2017].

[13] A. Turczak. „Problemy ochrony patentowej w Polsce”. Equilibrium, no. 1, pp. 203-216, 2010.

[14] United States Patent and Trademark Office. General Information Concerning Patents. USA Department of Commerce, 2014.

[15] United States Patent and Trademark Office. Fees and payment. Internet: www.uspto.gov/learning-andresources/fees-and-payments, Jan. 16, 2018 [Nov. 30, 2017].

[16] United Stated Patent and Trademark Office. Patent process overview. Internet: www.uspto.gov/patentsgetting-started/patent-process-overview, Jun. 9, 2017 [Dec. 29, 2017].

[17] United States Patent and Trademark Office. Process for Obtaining a Utility Patent. Internet: www.uspto.gov/patents-getting-started/patentbasics/types-patent-applications/utility-patent/ process-obtaining, Nov. 18, 2015 [Dec. 29, 2017].
[18] United States Patent and Trademark Office. Support Centers. Internet: www.uspto.gov/learning-andresources/support-centers, Nov. 17, 2014 [Nov. 30, 2017].

[19] R. Wolniak. "Innovation in the context of economic situation in the EU countries". Zeszyty Naukowe Akademia Morska w Szczecinie, no. 24, pp. 141-147, 2010.

[20] R. Wolniak. „Metody i narzędzia Lean Production i ich rola w kształtowaniu innowacji w przemyśle" in Innowacje w zarzqdzaniu i inżynierii produkcji. R. Knosala, Ed. Opole: Oficyna Wydawnicza Polskiego Towarzystwa Zarządzania Produkcją, 2013, pp. 524-534.

[21] R. Wolniak. "Relationship between selected lean management tools and innovations". Zeszyty Naukowe Politechniki Ślqskiej, s. Organizacja i Zarzqdzanie, no. 75, pp. 157-266, 2014.

[22] R. Wolniak. "The role of QFD method in creating innovation". Systemy Wspomagania Inżynierii Produkcji, vol. 15, no. 3, pp. 127-134, 2016.

[23] R. Wolniak and B. Skotnicka-Zasadzień. "The use of value stream mapping to introduction of organizational innovation in industry". Metalurgija, vol. 53, no. 4, pp. 709-712, 2014.

[24] R. Wolniak and M.E. Grebski. "Innovativeness and creativity as factors in workforce development - perspective of psychology". Zeszyty Naukowe Politechniki Ślqaskiej, s. Organizacja i Zarzq̨dzanie, in print.

[25] R. Wolniak and M.E. Grebski. "Innovativeness and creativity as nature and nurture". Zeszyty Naukowe Politechniki Ślq̨skiej, s. Organizacja i Zarzqdzanie, in print.

[26] R. Wolniak and M.E. Grebski. "Innovativeness and creativity of the workforce as factors stimulating economic growth in modern economies". Zeszyty Naukowe Politechniki Ślaskiej, s. Organizacja i Zarzqdzanie, in print.

\author{
Michalene Eva Grebski, Adjunct Instructor \\ Northampton Community College - Monroe Campus, USA \\ e-mail:mgrebski@northampton.edu \\ dr hab. inż. Radosław Wolniak, prof. PŚ \\ Silesian University of Technology \\ Faculty of Organization and Management \\ Institute of Production Engineering \\ ul. Roosevelta 26, 41-00 Zabrze, POLAND \\ e-mail: rwolniak@polsl.pl
}

